ISSN 1392-3196 / e-ISSN 2335-8947

Zemdirbyste-Agriculture, vol. 108, No. 3 (2021), p. 247-254

DOI 10.13080/z-a.2021.108.032

\title{
Effect of cultivation method of Panicum virgatum and soil organic matter content on the biomass yield
}

\author{
Maryna GALYTSKA ${ }^{1}$, Maksym KULYK ${ }^{1}$, Dzhamal RAKHMETOV ${ }^{2}$, \\ Vasyl KURYLO ${ }^{3}$, Ilona ROZHKO ${ }^{1}$ \\ ${ }^{1}$ Poltava State Agrarian Academy \\ 1/3 Skovorody, 36003 Poltava, Ukraine \\ E-mail: maryna.galytska@pdaa.edu.ua \\ ${ }^{2}$ National Academy of Sciences of Ukraine, M. M. Gryshko National Botanical Garden \\ Timiryazevskaya 1, 01014 Kyiv, Ukraine \\ ${ }^{3}$ Vinnytsia National Agrarian University \\ Sonyachna 3, 21008Vinnytsia, Ukraine
}

\begin{abstract}
The relevance of the research lies in tackling an important problem: mitigating anthropogenic environmental impacts. This is achieved by using the biomass of energy crops. The article investigates the impact of sole, strip and mixed crops of switchgrass (Panicum virgatum L.) with red clover (Trifolium pratense L.) on soil organic matter (SOM) content and biomass yield. This enables reduction of the anthropogenic load on agrophytocenoses, improves ecological production as well as increases the yield of the main component switchgrass. The objectives of this experiment were to evaluate the dynamics of the SOM content in energy crops of switchgrass and to determine the impact of SOM content on switchgrass yield. The experiment involved field trials with the introduced switchgrass cultivar 'Cave-in-Rock' during the period of 2011-2018. The experiment was aimed at determining the dynamics of SOM content, the yield level of switchgrass biomass depending on the type of sowing under the conditions of the forest-steppe. The studied factors are experimental years (2011-2018) and three switchgrass sowing methods: sole crop, strip switchgrass with red clover (strip crop) and mixed switchgrass with red clover (mixed crop). In the experiment, general and special methods were used: method of scientific research in agronomy; laboratory methods to determine SOM content and dry matter content in biomass; quantitative-weight method to establish switchgrass yield. The results of the study show that red clover in strip crops survived for 3-4 years and acting as bioherbicides in the row-spacing of switchgrass had a protective function, preventing from weeds germinating. Subsequently, legume aftereffect is observed for 2-3 years after sowing. In general, switchgrass growing in strip crop, in comparison with sole crop, provides the increase (by $0.02-0.045 \%$ ) of SOM content, which results in the increase (by $0.10-0.13 \mathrm{~kg} \mathrm{~m}^{-2}$ ) of dry biomass yield. This is confirmed by a strong correlation between the indicators: the correlation coefficient in strip crop was $r=0.93$, in mixed crop $-r=0.92$ and in sole crop $-r=$ $0.91(p<0.05)$.

Thus, the cultivation of switchgrass by the proposed methods will improve the environment and produce sustainable biomass for the production of biofuels. In the long run, this can reduce the energy dependence of the developing countries, including Ukraine.
\end{abstract}

Key words: soil organic matter, energy crops, switchgrass, clover, yield, biomass.

\section{Introduction}

Soil degradation is one of the urgent issues that international and world organizations pay more and more attention to. This negative impact directly affects the implementation of the Sustainable Development Goals, adopted by all United Nations members in 2015 that contain the action plan and evaluation criteria made till 2030. Also, a very important issue is reduction of the use of nonrenewable resources of our planet and the wider involvement of alternative energy sources including plant biomass.

Today, the current development rate of the bioenergy sector is insufficient in Ukraine and in other developing countries (Kalinichenko et al., 2017; Gorb et al., 2018). To achieve the goals of the National Renewable Energy Action Plan for the period until 2020, Ukraine needs to create a competitive biofuel market. It is also necessary to ensure free access of enterprises to waste or by-products of forestry and agriculture as well as to establish a biofuel stock exchange for sale and purchase of various types of biofuels from plant materials (Sanderson et al., 2006; Geletukha, Zheliezna, 2017).

The research of Geletukha et al. (2015) analysed the disadvantages of energy crops as a fuel and proposed

Please use the following format when citing the article:

Galytska M., Kulyk M., Rakhmetov D., Kurylo V., Rozhko I. 2021. Effect of cultivation method of Panicum virgatum and soil organic matter content on the biomass yield. Zemdirbyste-Agriculture, 108 (3): 251-258. DOI 10.13080/z-a.2021.108.032 
the ways to mitigate their negative impact. The current state and development prospects of this sector in Ukraine were considered. The concept of energy crops' cultivation in Ukraine was offered. The concept of cultivation of energy crops in Ukraine for solving social, economic and natural problems was proposed. Alongside this, it was determined that the switchgrass is suitable for cultivation on marginal lands (Evanylo et al., 2005) because of its relatively low water and nutrient requirements and positive environmental benefits (Sanderson et al., 1996; Vogel et al., 2002). Our new research has found ways to optimize the efficiency of production of switchgrass biomass depending on the technology of cultivation (Kulyk et al., 2020).

Currently constraints still remain in terms of economic production of switchgrass for biomass feedstock including reliable establishment practices to ensure productive stands in the seeding year, efficient use of fertilizers and more efficient methods to convert lignocellulose to biofuels. Cultivation of perennial grasses originating from temperate latitudes, including switchgrass, can reduce $\mathrm{CO}_{2}$ accumulation (Taranenko et al., 2019).

Today, comprehensive research on energy crops and improving the technology of their cultivation on marginal lands is becoming of high priority, since non-agricultural lands do not always demonstrate good agrochemical indicators, in particular low nutrient content, especially nitrogen. To solve this problem, basic, starter fertilizers and crop fertilizing, affecting the cost of the final yields of raw materials, are applied. In connection with the outlined problem, the issue of the reduced use of synthetic mineral fertilizers by attracting natural nitrogen in energy crops' nutrition needs to be solved. The use of atmospheric nitrogen that can be fixed by legumes is the easiest way. The previous studies support this hypothesis. Kuptsov and Popov (2015) determined the effectiveness of using companion crops for accumulation of nutrients in biomass, which are easily washed out of the soil without these crops, especially after dying away and mowing the main crop. The authors state the following advantages of lupine for strip sowing with energy crops: additional nitrogen nutrition of the main crop, high-quality horizontal drainage for soils and bio-herbicidal screen that suppresses weed growth and development, etc.

Among energy plants, switchgrass is a highly adaptable, drought-resistant and unpretentious crop. Switchgrass (Panicum virgatum L.) is a perennial plant from the Poaceae family. Yield of aboveground dry phytomass is $10-15 \mathrm{tha}^{-1}$, and seed yield amounts to 500 600 (sometimes up to 1000 ) $\mathrm{kg} \mathrm{ha}^{-1}$. Energy productivity of plants is 40-60 (up to 80) Gcal ha ${ }^{-1}$ (Kurylo et al., 2018). Red clover (Trifolium pratense L.) is a perennial fodder plant from the Fabaceae family.

It was determined that soil is the largest organic carbon $\left(\mathrm{C}_{\text {oro }}\right)$ system of the terrestrial ecosystems on the Earth, which strongly interacts with the composition of the atmosphere, climate and soil (Jobbágy, Jackson, 2000). An integral part of any soil is organic matter - a complex of biomass and plant residues, animals, microorganisms and their metabolic products. It was determined that the storage of $\mathrm{C}_{\text {org }}$ in the soil depends on the balance between input and losses of $\mathrm{C}$. The storage processes of $\mathrm{C}_{\text {org }}$ or its loss affect biotic characteristics such as biomass production and the number of microorganisms, average annual rainfall and temperature, soil characteristics, including texture and lithology, and anthropogenic activities such as land use and management (Albaladejo et al., 2013).

Reasonable management of soil organic carbon (SOC) is crucial for soil fertility as well as for mitigating and adapting to climate change, especially in the areas subject to desertification (Aguilera et al., 2018). Knowledge of how management methods affect the availability of nutrients for perennial grasses growth that is a key function of SOC is limited in various managed agro-ecosystems (Hoyle et al., 2013; Agostini et al., 2015). Also, the management of the switchgrass growing technology has not been fully improved, the use of switchgrass in feed production has not been fully studied, and the economic efficiency of its cultivation has not been entirely justified (Mitchell et al., 1994; Gumentyk, Kharytonov, 2018; Kalinichenko, Kulyk, 2018).

Given the known research in this area and our previous study (Taranenko et al., 2019), there is a hypothesis that must be confirmed or refuted: (1) Will the soil organic matter (SOM) content be changed in different ways with long-term cultivation of switchgrass: sole crop, strip crop and mixed crop? (2) How long can perennial legume (clover) persist in the phytocenosis of switchgrass? (3) How will the methods of switchgrass growing affect the dynamics of the annual change in biomass yield?

Therefore, the objectives of our experiment were to evaluate the dynamics of the organic matter content in the soil under switchgrass crops and to determine the impact of soil organic matter on switchgrass yield.

\section{Materials and methods}

A permanent experiment was performed in 2011-2018 at Poltava Experimental Field in the central part of the forest-steppe zone of Ukraine. The main soil properties $(0-30 \mathrm{~cm}$ depth) at the experimental site were: soil type - Haplic Luvisol (according to WRB, 2014), organic matter $-3.17 \%$, nitrogen $(\mathrm{N})-81 \mathrm{mg} \mathrm{kg}^{-1}$ dry soil, phosphorus (P) - $139 \mathrm{mg} \mathrm{kg}^{-1}$ dry soil, potassium $(\mathrm{K})-118 \mathrm{mg} \mathrm{kg}^{-1}$ dry soil, acidity $(\mathrm{pH})-6.8$.

The study of switchgrass was carried out according to the two-factor scheme of multi-year experiments. The accounting area of the plot was 5.0 $\mathrm{m}^{2}$, the plots were replicated four times. Arrangement of the plots in the experiment was according to the systemic alternation of the treatments in replications. The experiment was established and carried out taking into account all the requirements of the experimental technique in agronomy (Dospekhov, 1985).

A field experiment with the introduced switchgrass (Panicum virgatum L.) cultivar 'Cave-inRock' was carried out during the period of 2011-2018. The experiment was aimed at determining the dynamics of soil organic matter (SOM) content, the yield level of switchgrass biomass depending on the type of sowing in the conditions of the forest-steppe.

The studied factors: factor A - experimental years (2011-2018), factor B - sowing methods: 1 - sole crop switchgrass (sole crop), 2 - strip switchgrass with red clover (strip crop), 3 - mixed switchgrass with red clover (mixed crop) (Figure 1).

Sole crop (Sc) is switchgrass sowing by a wide $(45 \mathrm{~cm})$ row. The seeding rate was $5.7 \mathrm{~kg} \mathrm{ha}^{-1}$, the seed placement depth was up to $1.5 \mathrm{~cm}$. The sowing period was the second half of April. Strip sowing (Ss) - when red clover was sown in the row-spacings of switchgrass. The seeding rate of switchgrass was $5.7 \mathrm{~kg} \mathrm{ha}^{-1}$, red clover $-8.0 \mathrm{~kg} \mathrm{ha}^{-1}$, seed placement depth was up to $1.5 \mathrm{~cm}$. The sowing period of the components in strip crop was the second half of April. Mixed sowing (Ms) when the seeds of switchgrass and red clover were sown together. The seeding rate of switchgrass was $5.7 \mathrm{~kg} \mathrm{ha}^{-1}$, red clover $-8.0 \mathrm{~kg} \mathrm{ha}^{-1}$, seed placement depth was up to $1.5 \mathrm{~cm}$. The sowing period of the components in mixed crop was the second half of April.

The weather conditions during the growing season of switchgrass between 2011-2018 were favourable. In some periods, the air temperature was 

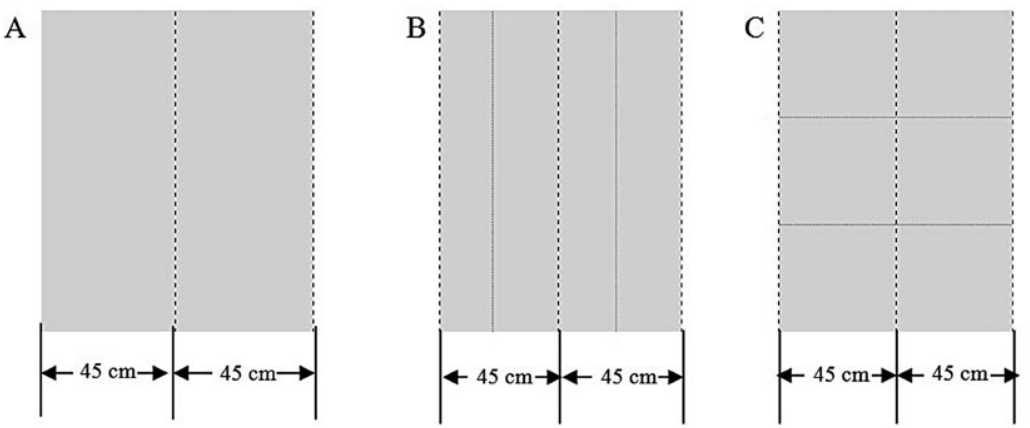

switchgrass

red clover

Figure 1. The scheme of sole (A), strip (B) and mixed (C) crops of switchgrass sowing with red clover

higher than the annual average and during the years of experiment the weather varied slightly. The amount of atmospheric precipitation was close to the annual average; in some periods of the growing season this figure was quite variable but had no significant effect on the biomass yield. Agrotechnical operations for switchgrass cultivation included ploughing, spring soil cultivation, seeding and rolling the crops. Multiple row soil cultivation was carried out after the emergence of switchgrass shoots in the frst year of crop establishment. In the following years, soil cultivation was not carried out. Switchgrass was sown in the first 10 days of May. The width between rows was 45 $\mathrm{cm}$. For seeding the legume, clover and switchgrass, the seed box of the drill was divided into sections by metal partitions to create rows of legume and the grass. The depth of sowing was $1-1.5 \mathrm{~cm}$.

The experiments comprised the following planned accounting, determination of biomass yield, analyses and calculations: planning, laying and conducting experiments according to the methodology of scientific research in agronomy (Elbersen et al., 2013). Determination of SOM content was carried out according to ISO 14235:1998 (Determination of organic carbon by sulfochromic oxidation). Switchgrass biomass yield was determined by weighing sheave samples from each plot of land of aboveground vegetative mass with subsequent recalculation of it on dry mass in accordance with the moisture content of raw material (Kulyk, 2016; Kulyk et al., 2017). Dry matter content in plant material was determined by drying the sample to a completely dry mass in a drying box at a $100-105^{\circ} \mathrm{C}$ temperature for $4-6$ hours followed by cooling, weighing the samples and corresponding recalculation (Kulyk, 2016).

Statistical analysis of the experimental results was performed by multivariate analysis of variance (MANOVA).

\section{Results and discussion}

Dynamics of soil organic matter (SOM) content depending on the type of switchgrass crop. It was determined that depending on the type of switchgrass crops the dynamics of SOM content changed and varied in the range of $3.17 \%$ (0 year) to $3.25-3.31 \%\left(6^{\text {th }}\right.$ year $)$ with the subsequent decrease to $3.23-3.29 \%$ ( $8^{\text {th }}$ year) (Figure 2).

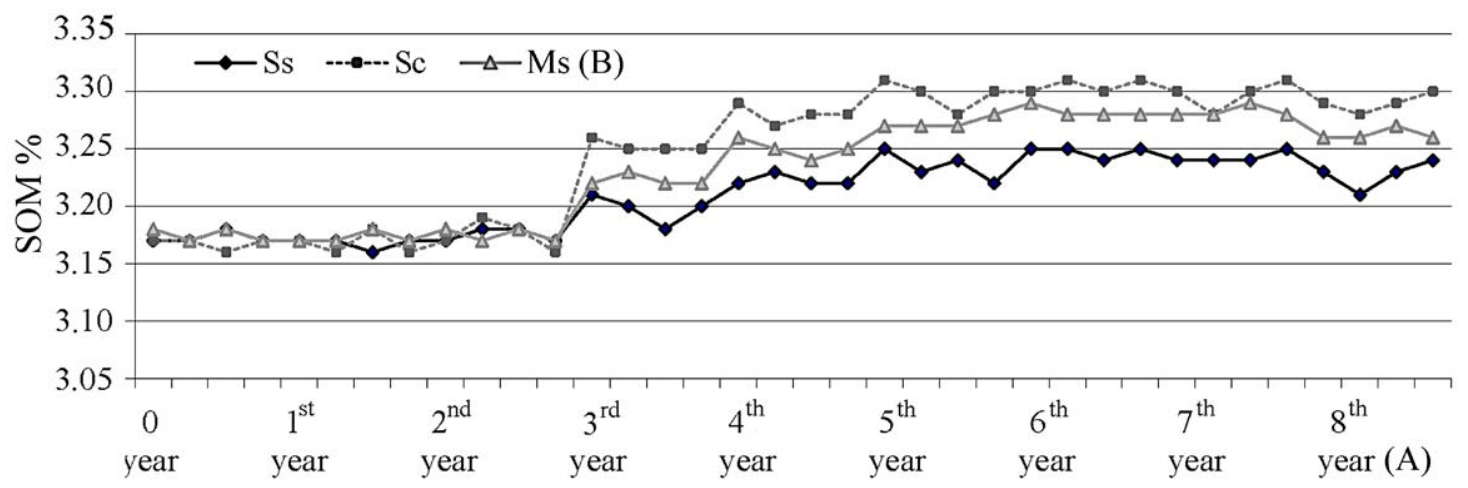

$\mathrm{Sc}$ - sole crop sowing, $\mathrm{Ss}$ - strip sowing with red clover, $\mathrm{Ms}$ - mixed sowing with red clover; $\mathrm{LSD}_{05}$ (factor A - experimental year) $0.021, \mathrm{LSD}_{05}$ (factor B - type of crop) 0.023, $\mathrm{LSD}_{05}$ (factors A and B) 0.014

Figure 2. Dynamics of soil organic matter (SOM) content depending on the type of switchgrass crop and the experimental year (2011-2018)

A tendency toward the increase of SOM content appeared from the second vegetation year, when the legume component red clover intensively grew in the phytocenosis, which is associated with the life period of clover, the increase during the $4-6^{\text {th }}$ year (due to aftereffect) and the slight decrease during the $7-8^{\text {th }}$ year of vegetation (Figure 3 ).

Figures 4 and 5 show the graphic representation of the dependence of SOM content on the year and the type of switchgrass crops during the period of 2011-
2018 taking into account the level of significance $(p)$. According to these dependences, sole crop was clearly separated from the other types of switchgrass crops (Figure 4A). The increase of SOM content was observed both over the years and on average over the experimental years (Figure 4B).

This multiplication dependence shows a gradual increase in the SOM content over the years and taking into account the type of switchgrass crops. The highest value for this indicator was in strip crop of switchgrass 


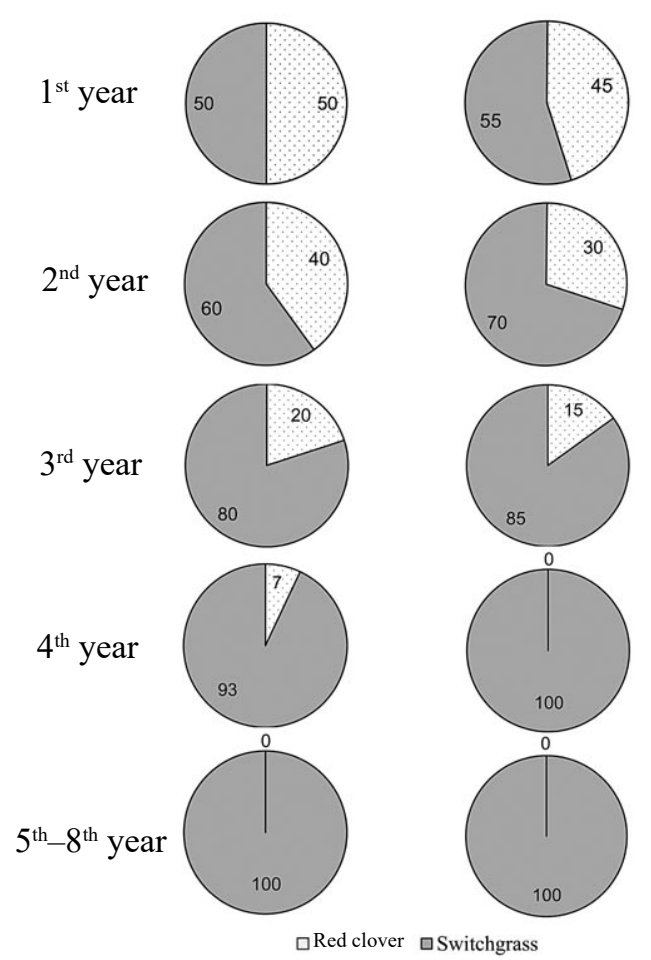

Figure 3. Dynamics of phytocenosis structure in strip (A) and mixed (B) crops of switchgrass over the experimental years (2011-2018)

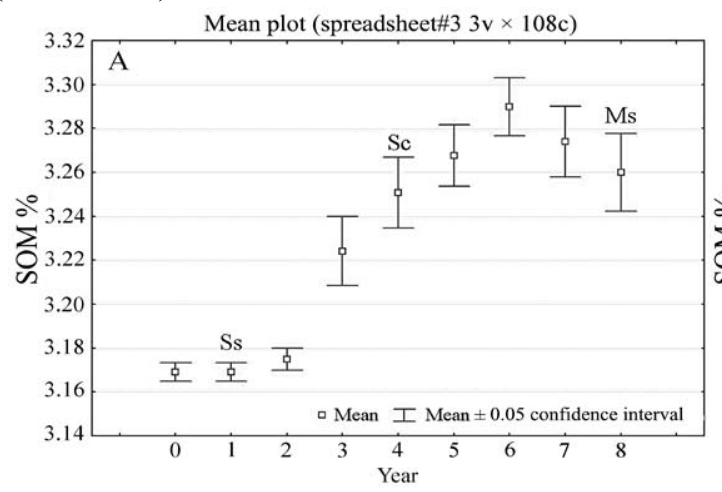

with red clover. It was assumed that this trend depended on the increase in $\mathrm{N}$ content in the soil that clover accumulated.

It is also important to leave the roots in the soil with a related crop (clover). The result of experiment by Aguilera et al. (2018) shows that roots represented the majority of carbon inputs across most of the crop-management categories. Crop carbon allocated underground represented a very significant fraction of soil organic carbon (SOC) inputs. The regularity of changes in SOM content over the experimental years depending on the type of switchgrass sowing was confirmed by the MANOVA $(p<0.05)$ (Table 1).

MANOVA showed significant differences $(p<$ 0.05 ) in the SOM content from the experimental year, the type of switchgrass crops and their interaction at significance levels.

The yield of switchgrass biomass depending on SOM content and the type of crop. The yield of dry switchgrass biomass depending on SOM content and the type of crop varied in the range of 0.50 to $1.62 \mathrm{~kg} \mathrm{~m}^{-2}$ (Figure 6). In comparison with sole crops, in mixed crops the yield increased by $0.13 \mathrm{~kg} \mathrm{~m}^{-2}$, in strip crops - by $0.10 \mathrm{~kg} \mathrm{~m}^{-2}$.

On average, throughout the experimental years, strip crops provided the highest average value of switchgrass biomass yield $\left(1.28 \mathrm{~kg} \mathrm{~m}^{-2}\right)$ in comparison with sole crop $\left(1.15 \mathrm{~kg} \mathrm{~m}^{-2}\right)$ and mixed crop provided lower value $\left(1.25 \mathrm{~kg} \mathrm{~m}^{-2}\right)$. The differences between the treatments are confirmed by the statistical analysis (Table 2).

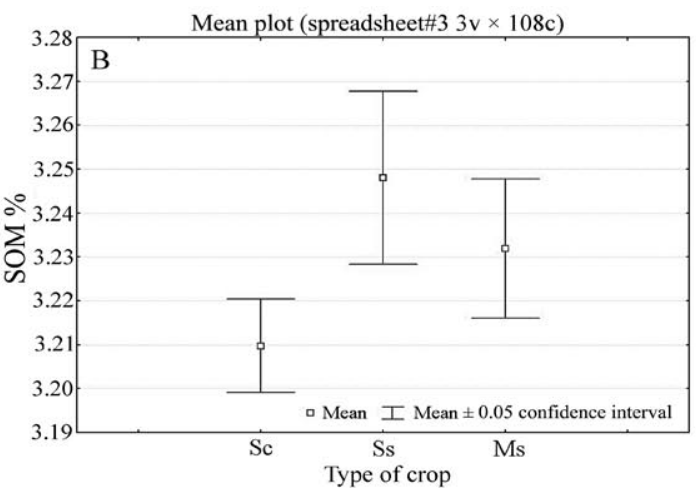

$\mathrm{Sc}$ - sole crop sowing, Ss - strip sowing with red clover, Ms - mixed sowing with red clover

Figure 4. Dependence of soil organic matter (SOM) content on the experimental year (A) and the type of switchgrass crops (B) (2011-2018)

Table 1. MANOVA of the dependence of organic matter content in the soil on the experimental year, the type of switchgrass crops and their interaction

\begin{tabular}{|c|c|c|c|c|c|}
\hline & $\begin{array}{c}\text { Sum } \\
\text { of squares }\end{array}$ & $\begin{array}{c}\text { Degree } \\
\text { of freedom }\end{array}$ & $\begin{array}{l}\text { Middle } \\
\text { square }\end{array}$ & $F$ & $p$ \\
\hline Intercept & 1126.689 & 1 & 1126.689 & 17138362 & $<0.05$ \\
\hline Year & 0.211 & 8 & 0.026 & 400 & $<0.05$ \\
\hline Type of crop & 0.027 & 2 & 0.013 & 203 & $<0.05$ \\
\hline Year $\times$ type of crop & 0.015 & 16 & 0.001 & 14 & $<0.05$ \\
\hline Error & 0.005 & 81 & 0.000 & & \\
\hline
\end{tabular}

$F$ - Fisher's criterion, $p$ - level of significance

Table 2. MANOVA of the dependence of switchgrass biomass yield on the year of life, the type of crop and their interaction

\begin{tabular}{ccccc}
\hline & Sum & Middle & $F$ \\
of squares & $\begin{array}{c}\text { Degre } \\
\text { of freedom }\end{array}$ & square & $p$ \\
\hline Intercept & 162.6560 & 1 & 162.6560 & 2395480 \\
Year & 14.7318 & 8 & 1.8415 & 27120 \\
Type of crop & 0.3179 & 2 & 0.1590 & $<0.05$ \\
Year $\times$ type of crop & 0.1529 & 16 & 0.0096 & 2341 \\
Error & 0.0055 & 81 & 0.0001 & 141 \\
\hline
\end{tabular}

$F$ - Fisher's criterion, $p$ - level of significance 


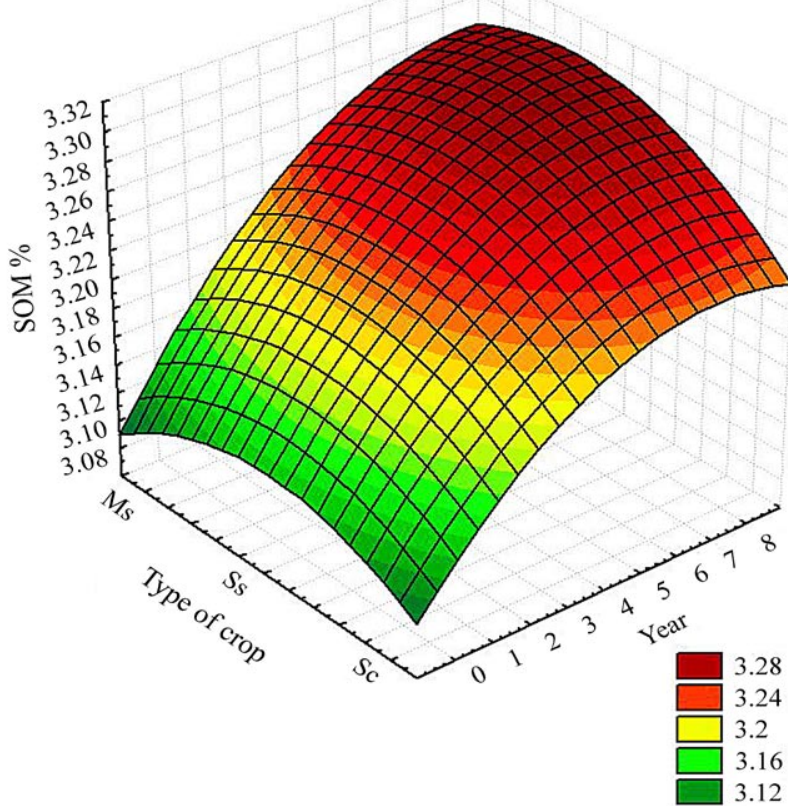

Sc - sole crop sowing, Ss - strip sowing with red clover, Ms - mixed sowing with red clover

Figure 5. Multiplication dependence of soil organic matter (SOM) content on the switchgrass sowing method and the experimental year (2011-2018)
The research of the cultivation year impact shows the following dependence: switchgrass yield increased every year. In total, an average value of this indicator increased by $0.38 \mathrm{~kg} \mathrm{~m}^{-2}$ during the period of 2011-2018. During one year of the experiment, switchgrass yield increased on average by $0.05-0.07 \mathrm{~kg}$ $\mathrm{m}^{-2}$ for the minimum and maximum values of the yield indicator, 0.49 and $1.63 \mathrm{~kg} \mathrm{~m}^{-2}$, respectively (Figures 7 and 8). According to the research results, it can be concluded that over many years of switchgrass growing biomass yield increased annually.

Strip crop provided the maximum switchgrass yield over the experimental years $-1.62 \mathrm{~kg} \mathrm{~m}^{-2}$, and the sole crop provided the lowest yield $-1.15 \mathrm{~kg} \mathrm{~m}^{-2}$. The difference between switchgrass biomass yield in strip and mixed crops was $0.03 \mathrm{~kg} \mathrm{~m}^{-2}$.

A number of advantages were determined while growing switchgrass in strip and mixed crops with legume component (red clover): 1) legumes have some peculiarities of the root system structure in terms of its location in the horizontal areas of the soil profile and grain crops in the vertical ones; this is associated with the root system, which allows using natural soil fertility in a better way; 2) switchgrass and clover assimilate $\mathrm{N}$ differently - the legume crop has the ability to fix it from the atmosphere; as a result of this, the green mass of grainlegume mixtures is more efficient by biomass comparing to grain (switchgrass) crop in sole crop; 3 ) creation of a specific microclimate promotes moisture growth, the increase of microbiological processes in the upper soil

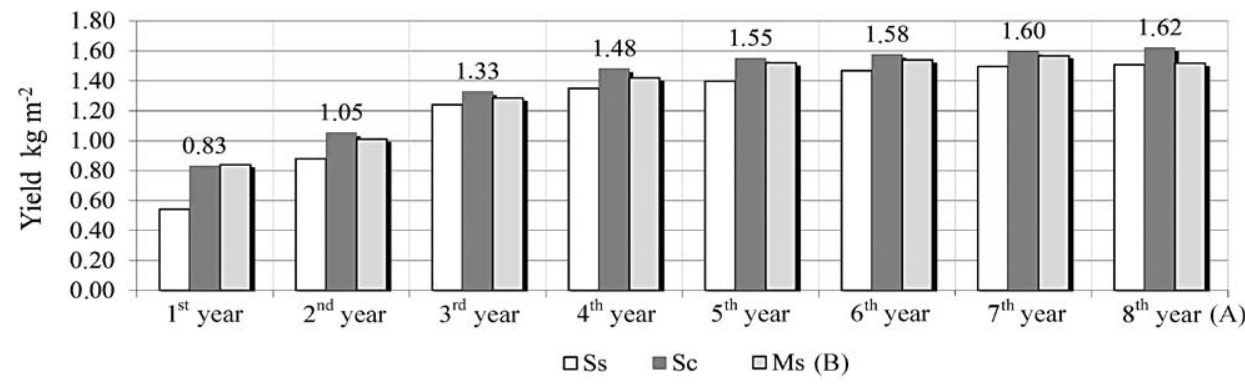

$\mathrm{Sc}$ - sole crop sowing, Ss - strip sowing with red clover, Ms - mixed sowing with red clover; $\mathrm{LSD}_{05}$ (factor A - experimental year) $0.066, \mathrm{LSD}_{05}$ (factor B - type of crop) $0.075, \mathrm{LSD}_{05}$ (A and B) 0.014

Figure 6. Dependence of switchgrass biomass yield on the type of crop (2011-2018)

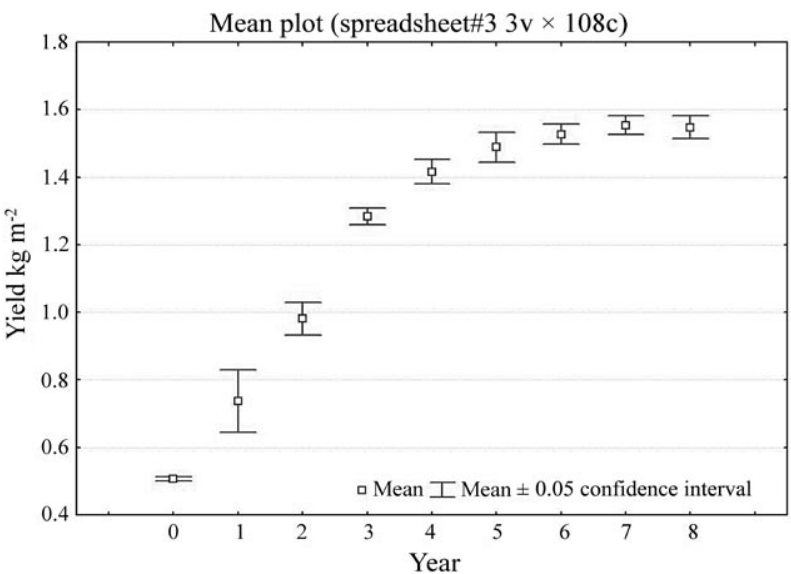

Figure 7. Dependence of switchgrass biomass yield on the experimental year (2011-2018)

layer that has a positive effect on the growth of the main crop (switchgrass) in strip crops; 4) different height of the plant components creates layering of crops, which allows plants of both components to better use solar energy; 5) leaf-stem mass of clover due to the intensive growth at the initial stages, and during restoration of spring vegetation covers the area between switchgrass plants creating a bio-herbicidal screen in strip crop reducing the amount of unwanted vegetation - weeds in row-spacings.

The findings agree with those obtained in the studies of Gettle et al. (1996). Scientists claim that the introduction of beans into the established sowing crop introduced switchgrass can provide symbiotic $\mathrm{N}$ fixation, improve the quality of grass and prolong the grazing season. Legumes did not seriously reduce switchgrass stem density, although red clover, birdsfoot trefoil and their mixture were more competitive than others. Legumes can be successfully introduced into established switchgrass cultivar 'Cave-in-Rock' by frost-seeding, and they will persist for at least two years with favourable weather.

These findings are consistent with previous studies (Ashworth et al., 2015) reporting the positive dynamics of increasing the sustainability of the production of feed and bio-raw materials by co-cultivation of switchgrass with red clover (Trifolium pratense L.), hairy eyelid (Vicia villosa L.), perennial clover (T. repens L.), arrowleaf clover (T. vesiculosum L.) and other legumes. Intercropping selected legumes in switchgrass may enhance forage quality and yield, while reducing nonrenewable inputs, fertilizer costs and emissions/runoff to air and groundwater (Ledgard et al., 2009). 


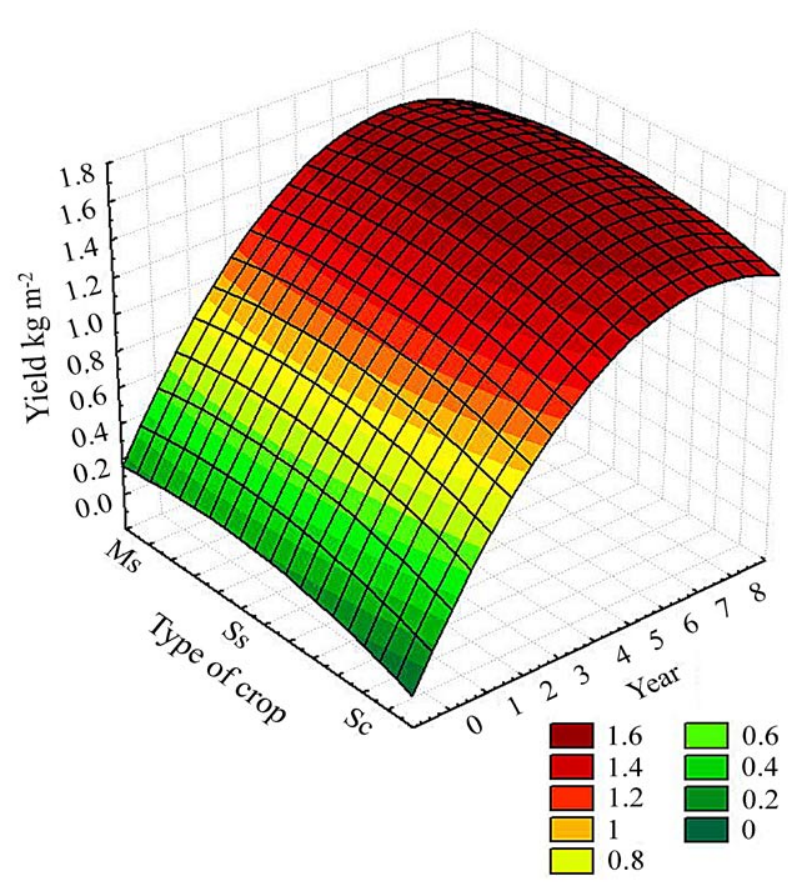

Sc - sole crop sowing, Ss - strip sowing with red clover, Ms - mixed sowing with red clover

Figure 8. Multiplication dependence of switchgrass biomass yield on the type of crop and the experimental year (2011-2018)
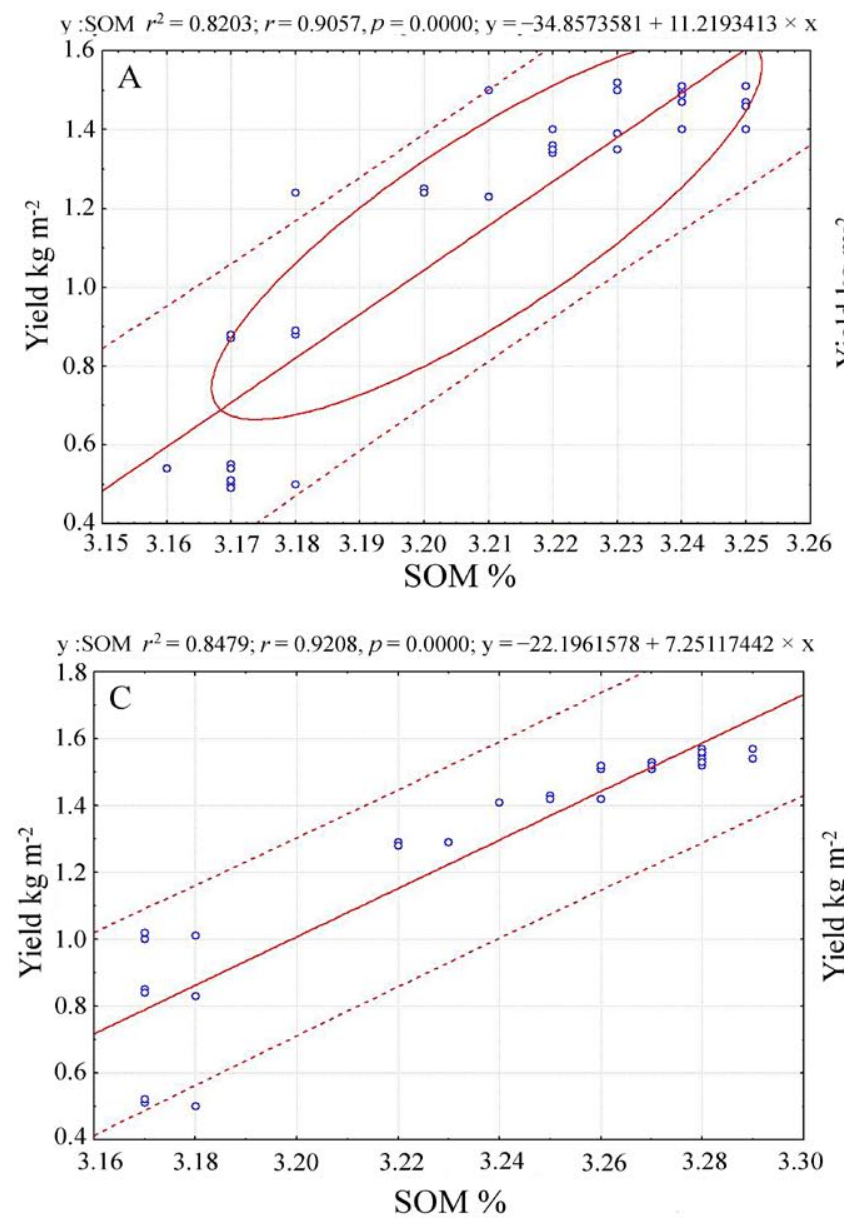

$\mathrm{ABC}$ - total impact of all sowing methods
Correlation between the switchgrass biomass yield and SOM content according to the type of crop. In general, it was determined that the yield of switchgrass dry biomass is closely related to SOM content. A significant positive correlation between biomass yield and SOM content was determined at a level of $r=0.89$. The correlation coefficient $(r)$ in strip crop was 0.93 , in mixed crop -0.92 , in sole crop - at a level of 0.91 with a significance level of $p<0.05$ (Figure 9).

The results of the experiment showed that in strip crop switchgrass was characterized by a significantly higher level of biomass yield in comparison with mixed and sole crops, while SOM content increased. This regularity can be associated with an increased SOM content under strip sowing crop, compared with mixed and sole crops. This was confirmed by the data of Franzluebbers et al. (2000).

Results of Murphy's (2015) research showed that SOM is a key indicator of soil quality and plays an important role in enhancing a range of soil physical, chemical and biological functions. The storage of $\mathrm{C}_{\text {org }}$ in the soil depends on the balance between gains and losses of carbon. Biotic characteristics such as biomass production and microbial abundance, mean annual precipitation and temperature, soil characteristics including texture and lithology and anthropogenic activities, like land use and management, influence the processes of SOC storage or losses. A clear description of the distribution and changes of SOC and its factors of control will help to predict the consequences of climate change (Albaladejo et al., 2013). In the soil ecosystem, SOC serves as a source of major plant nutrients such as N, P and S (Sarker et al., 2018).
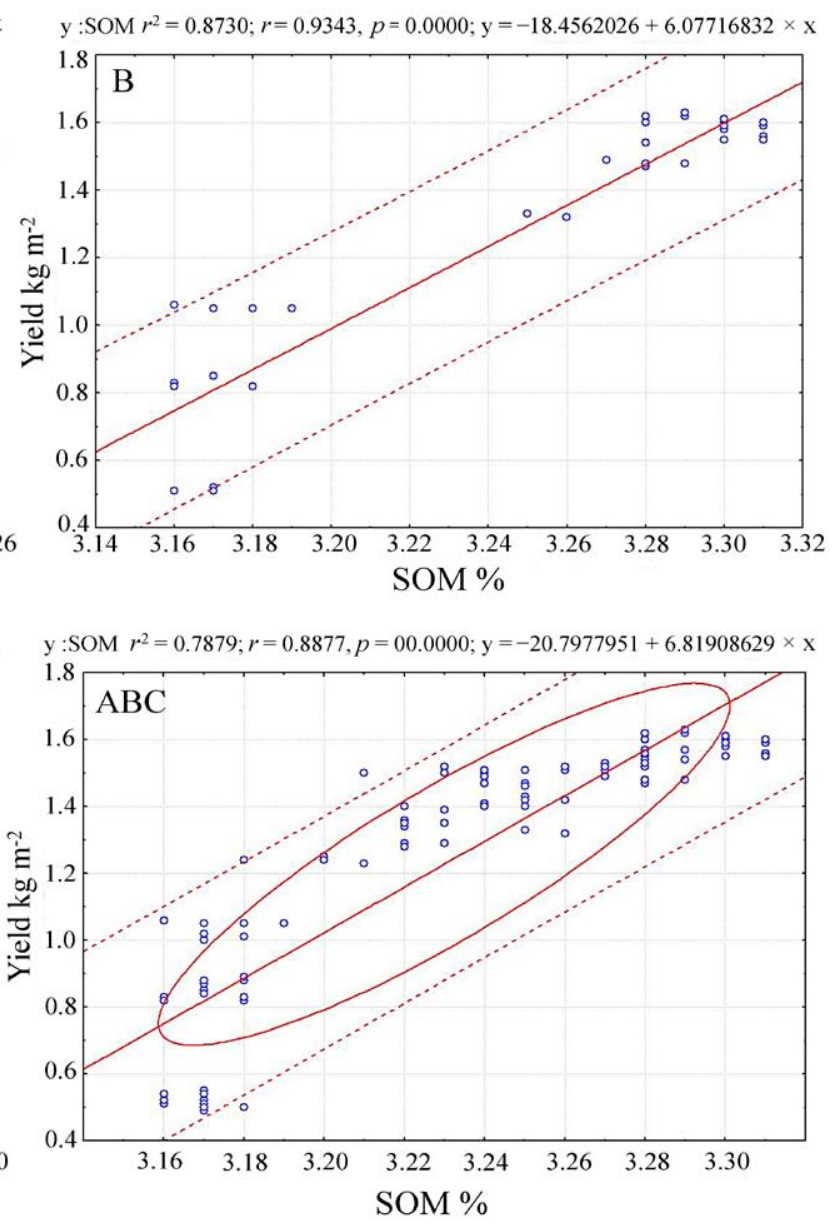

Figure 9. Dependence between switchgrass biomass yield (Y) and soil organic matter (SOM) content of sole (A), strip (B) and mixed (C) crops (2011-2018) 
Therefore, it can be concluded that switchgrass management for bioenergy stabilized soil properties over the years. Results of Sutie et al. (2019) agree with the findings of our experiment that switchgrass productivity depends on SOM content. They claim that in the long term, transgenic energy crops can produce more aboveground and underground biomass and increase the efficiency of biofuel production and sequestration of SOC. The authors suggest that aboveground and underground distribution of carbon inputs may be useful for restoration of marginal soil, especially at deeper layers. Therefore, switchgrass can be a sustainable energy crop successfully cultivated on poor agricultural soils or marginal lands, which will be a perspective for our further research.

\section{Conclusions}

1. In the strip crop, red clover grows up to 4 years, occupying the structure of phytocenosis from $50 \%$ (in the $1^{\text {st }}$ year) to $7 \%$ (in the $4^{\text {th }}$ year), in mixed crop it persists for up to 3 years from $45 \%$ to $15 \%$ (in the $3^{\text {rd }}$ year). Regardless of the type of crop, red clover aboveground vegetative mass performs a protective function against weeds, together with switchgrass accumulates nutrients in the soil as well as contributes to the increase of organic matter in it.

2. In comparison with the sole, strip and mixed crops of switchgrass and red clover provided $47-56 \%$ reduction of weeds, accelerated the intensity of the linear growth of plants (by $9.7-11.3 \mathrm{~cm}$ ) at the initial stages of organogenesis in the first year of life and, finally, increased soil organic matter (SOM) content (by $0.045 \%$ ) and enhanced dry biomass yield (by $0.10-0.13 \mathrm{~kg} \mathrm{~m}^{-2}$ ) by improving nitrogen $(\mathrm{N})$ nutrition of switchgrass plants and reducing the competition of the crop with weeds for light, water and nutrients. During the experimental period, there was a significant increase in the yield of switchgrass biomass up to $1.62 \mathrm{~kg} \mathrm{~m}^{-2}$ in strip crop, up to $1.52 \mathrm{~kg} \mathrm{~m}^{-2}$ in mixed crop; the lowest yield was produced by the sole crop $-1.15 \mathrm{~kg} \mathrm{~m}^{-2}$.

3. The yield of dry biomass of switchgrass depends on the SOM content. This was confirmed by the reliable coefficients of correlations $(r)$ between biomass yield and SOM content: for strip crop $(r=0.93)$, for mixed crop $(r=0.92)$ and for sole crop $(r=0.91)$.

The perspectives for further research will be to evaluate the response of switchgrass plants to cultivation with other legumes in strip and mixed crops.

Received 26102020

Accepted 03062021

\section{References}

Agostini F., Gregory A. S., Richter G. M. 2015. Carbon sequestration by perennial energy crops: is the jury still out? BioFnergy Research. 8 (3): 1057-1080. https://doi.org/10.1007/s12155-014-9571-0

Aguilera E., Guzmán G. I., Álvaro-Fuentes J., Infante-Amate J. García-Ruiz R., Carranza-Gallego G., Soto, D., González de Molina, M. 2018. A historical perspective on soil organic carbon in Mediterranean cropland (Spain, 1900-2008). Science of The Total Fnvironment 621: 634-648. https://doi.org/10.1016/j.scitotenv.2017.11.243

Albaladejo J., Ortiz R., Garcia-Franco N., Navarro A. R. Almagro M., Pintado J. G., Martínez-Mena M. 2013. Land use and climate change impacts on soil organic carbon stocks in semi-arid Snain. Iournal of Soils and Sediments, 13 (2): 265-277. https://doi.org/10.1007/s11368-012-0617-7

Ashworth A. J., Allen F. L., Keyser P. D., Tyler D. D., Saxton A. M., Taylor A. M. 2015. Switchgrass yield and stand dynamics from legume intercropping based on seeding rate and harvest management Inurnal of Soil and Water Conservation, 70 (6): 374. https://doi.org/10.2489/jswc.70.6.374
Dospekhov B. A. 1985. Methodology of field experience [Методика полевого опыта]. Moscow, Russia, 336 p. (in Russian). https://mf.bmstu.ru/info/faculty/lt/caf/lt1/ soil_books/uchebnik9.pdf

Elbersen H. W., Poppens R. P., Bakker R. R. C. 2013 Switchgrass (Panicum virgatum $\mathrm{L}$.). A perennial biomass grass for efficient production of feedstock for the biobased economy. NL Agency, Ministry of Economics Affairs, Agriculture and Innovation, $28 \mathrm{p}$. https://library.wur.nl/WebQuery/wurpubs/fulltext/282358

Evanylo G. K., Abaye A. O., Dundas C., Zipper C. E., Lemus R., Sukkariyah B., Rockett J. 2005. Herbaceous vegetation productivity, persistence, and metals uptake on a biosolidsamended mine soil. Journal of Environmental Ouality, 34 (5): 1811-1819. https://doi.org/10.2134/jeq2004.0329

Franzluebbers A. J., Stuedemann J. A., Schomberg H. H., Wilkinson S. R. 2000. Soil organic C and N pools under long-term pasture management in the Southern Piedmont USA. Soil Biology and Biochemistry. 32 (4): 469-478. https://doi.org/10.1016/S0038-0717(99)00176-5

Geletukha G., Zheliezna T., Tryboi O. V. 2015. Prospects for growing and use of energy crops in Ukraine. Part 2. Thermophysics and Thermal Power Engineering, 37 (5): 58-67. https://doi.org/10.31472/ihe.5.2015.07

Geletukha G. G., Zheliezna T. A. 2017. State of the art and prospects for bioenergy development in Ukraine. Industrial heat engineering, 39 (2): 60-64 (in Ukrainian).

http://dspace.nbuv.gov.ua/bitstream/handle/123456789/14 2351/10-Geletukha.pdf?sequence $=1$

Gettle R. M., George J. R., Blanchet K. M., Moore K. J., Buxton D. R. 1996. Frost-seeding legumes into established switchgrass: establishment, density, persistence, and sward composition. Agronomy Journal. 8 (1): 98-103. https://doi.org/10.2134/agronj1996.00021962008800010021x

Gorb O., Kostenko O., Kulyk M., Yasnolob I., Kalinichenko A. 2018. Energy crops: the link between education and science. Pietkun-Greber I., Suszanowicz D. (eds). Odnawialne Żródła Energii - teoria i praktyka, vol. III, p. 9-36. http://dspace.pdaa.edu.ua:8080/bitstream/123456789/4254 /1/Artyku\%C5\%82\%201\%20OZE\%202018\%20mono.pdf

Gumentyk M., Kharytonov M. 2018. Development and assessment of technologies of miscanthus and switchgrass growing in forest-steppe zone of Ukraine. Agriculture and Forestry. 64 (2): 137-146. https://doi.org/10.17707/AgricultForest.64.2.10

Hoyle F. C., D’Antuono M., Overheu T., Murphy D. V. 2013. Capacity for increasing soil organic carbon stocks in dryland agricultural systems. Soil Research, 51 (8): $657-$ 667. https://doi.org/10.1071/SR12373

Jobbágy E. G., Jackson R. B. 2000. The vertical distribution of soil organic carbon and its relation to climate and vegetation. Ecological Applications. 10 (2): 423-436. https://doi. org/10.1890/1051-0761(2000)010[0423:TVDOSO]2.0.CO;2

Kalinichenko A., Kalinichenko O., Kulyk M. 2017. Assessment of available potential of agro-biomass and energy crops phytomass for biofuel production in Ukraine. Pietkun-Greber I., Ratuszny P. (eds). Renewable energy sourcestheory and practice, vol. II, p. 163-179. http://dspace.pdaa.edu.ua:8080/handle/123456789/343

Kalinichenko O. V., Kulyk M. I. 2018. Economic efficiency of rod-shaped millet (switchgrass) cultivation within the forest-steppe of Ukraine. The Economy of Agro-Industrial Complex. 11: 19-28 (in Ukrainian). https://doi.org/10.32317/2221-1055.201811019

Kulyk M. I. 2016. Energy potential and economic efficiency of switchgrass phytomass production for biofuel. Scientific reports of NULES of Ukraine. 61 (4): 1-12 (in Ukrainian). https://doi.org/10.31548/dopovidi2016.04.010

Kulyk M. I., Rakhmetov D. B., Kurylo V. L. 2017. Methodology of conducting field and laboratory researches with switchgrass (Panicum virgatum L.). Poltava, Ukraine, 24 p. http://dspace.pdaa.edu.ua:8080/handle/123456789/7586 
Kulyk M., Kalynychenko O., Pryshliak N., Pryshliak V. 2020. Efficiency of using biomass from energy crops for sustainable bioenergy development. Journal of Environmental Management and Tourism. 11 (5): 10401053. https://doi.org/10.14505//jemt.v11.5(45).02

Kurylo V. L., Raxmetov D. B., Kulyk M. I. 2018. Biological features and potential of yield of energy crops of the thinskinned family in the conditions of Ukraine. Bulletin of Poltava State Agrarian Academy, 1: 11-17 https://doi.org/10.31210/visnyk2018.01.01

Kuptsov N. S., Popov E. G. 2015. Energy plantations. Handbook on the use of energy plants. National Academy of Sciences of Belarus, 128 p. (in Belarusian). http://hbc.bas-net.by/hbcinfo/books/Kuptsov2015-2.pdf

Ledgard S., Schils R., Eriksen J., Luo J. 2009. Environmental impacts of grazed clover/grass pastures. Irish Journal of Agricultural and Food Research, 48 (2): 209-226. https://www.jstor.org/stable/20720369

Mitchell R. B., Moser L. E., Anderson B., Ta Waller S. S. 1994 Switchgrass, big bluestem, and indiangrass for grazing and hay. Historical Materials from the University of NebraskaLincoln, Paper 1314. https://digitalcommons.unl.edu/ extensionhist $/ 1314$

Murphy B. W. 2015. Impact of soil organic matter on soil properties - a review with emphasis on Australian soils. Soil Research. 53 (6): 605-635. https://doi.org/10.1071/SR14246

Sanderson M. A., Reed R. L., McLaughlin S. B., Wullschleger S. D., Conger B. V, Parrish D. J., Wolf D. D., Taliaferro C., Hopkins A. A., Ocumpaugh W. R., HusseyM. A., Read J. C.,
Tischler C. R. 1996. Switchgrass as a sustainable bioenergy cron. Bioresource Technology. 56 (1): 83-93. https://doi.org/10.1016/0960-8524(95)00176-X

Sanderson M. A., Adler P. R., Boateng A. A., Casler M. D., Sarath G. 2006. Switchgrass as a biofuels feedstock in the USA. Canadian Journal of Plant Science, 86 (5): 13151325. https://doi.org/10.4141/P06-136

Sarker J. R., Singh B. P., Dougherty W. J., Fang Y., Badgery W., Hoyle F. C., Dalal R. C., Cowie A. L. 2018. Impact of agricultural management practices on the nutrient supply potential of soil organic matter under long-term farming svstems. Soil and Tillage Research. 175: 71-81. https://doi.org/10.1016/j.still.2017.08.005

Sutie X., Ottinger L., Sarah, Sean M., Schaefer J. M., DeBruyn C., Stewart Jr. C. N., Mazarei M., Jagadamma S. 2019. Effects of field-grown transgenic switchgrass carbon innuts on soil organic carbon cvcling. PeerJ, 7: e7887. https://doi.org/10.7717/peerj.7887

Taranenko A., Kulyk M., Galytska M., Taranenko S. 2019. Effect of cultivation technology on switchgrass (Panicum virgatum L.) productivity in marginal lands in Ukraine. Acta Agrobotanica. 72 (3): 1-11. https://doi.org/10.5586/aa. 1786

Vogel K. P., Brejda J. J., Walters D. T., Buxton D. R. 2002. Switchgrass biomass production in the midwest USA: Harvest and nitrogen management. Agronomv Journal, 94 (3): 413-420. https://doi.org/10.2134/agronj2002.0413

WRB. 2014. World reference base for soil resources. World Soil Resources Reports No. 106. FAO, 189 p. http://www.fao.org/3/i3794en/I3794en.pdf

\title{
Panicum virgatum auginimo būdo ir dirvožemio organinès medžiagos kiekio ịtaka biomasès derliui
}

\author{
M. Galytska ${ }^{1}$, M. Kulyk¹, D. Rakhmetov ${ }^{2}$, V. Kurylo ${ }^{3}$, I. Rozhko ${ }^{1}$ \\ ${ }^{1}$ Poltavos valstybinė agrarinè akademija, Ukraina \\ ${ }^{2}$ Ukrainos nacionalinė mokslų akademijos M. M. Gryško nacionalinis botanikos sodas \\ ${ }^{3}$ Vinycios nacionalinis žemės ūkio universitetas, Ukraina
}

\section{Santrauka}

Tyrimų aktualumą lemia svarbios problemos sprendimas - antropogeninio poveikio aplinkai mažinimas. Tai pasiekiama naudojant energinių augalų biomasę. Straipsnyje analizuojama juostomis pasètų rykštinès soros (Panicum virgatum L.) ir jos mišinių su raudonaisiais dobilais (Trifolium pratense L.) pasèlių ịtaka dirvožemio organinès medžiagos (DOM) kiekiui ir biomasès derliui. Tai leidžia sumažinti agrofitocenozių antropogeninę apkrovą, pagerinti ekologinę gamybą ir padidinti pagrindinio komponento rykštinių sorų žolès derlių. Eksperimento tikslai - įvertinti DOM kiekio dinamiką rykštinių sorų pasèliuose ir nustatyti SOM kiekio įtaką jos derliui. Eksperimento metu 2011-2018 m. buvo atlikti lauko bandymai su introdukuota rykštinès soros veisle 'Cave-inRock'. Eksperimentu siekta nustatyti DOM kiekio dinamiką, sorų biomasès derliaus lygi priklausomai nuo sėjos būdo miškostepès sąlygomis. Tyrimo veiksniai - eksperimento metai (2011-2018 m.) ir trys soru sèjos būdai: vienanaris pasėlis, juostinè sejja su raudonaisiais dobilais (juostinis pasèlis) ir mišinys su raudonaisiais dobilais (mišrus pasèlis). Eksperimente taikyti bendrieji ir specialieji metodai: agronomijos mokslinio tyrimo metodas pagal Dospekhovą, laboratoriniai metodai DOM kiekiui ir sausujų medžiagu kiekiui biomasejje nustatyti ir kiekybinis svorio metodas sorų žolès derliui nustatyti. Tyrimo rezultatai rodo, kad juostiniuose pasèliuose raudonieji dobilai išsilaikẻ 3-4 metus, o veikdami kaip bioherbicidai sorų tarpueiliuose atliko apsauginę funkciją, neleisdami sudygti piktžolėms. Pupinių augalų įtaka nustatyta 2-3 metus po sèjos. Juostiniu būdu pasètame pasèlyje augintos soros, palyginti su jų vienanariu pasèliu, užtikrino DOM kiekio padidejjimą $(0,02-0,045 \%)$, o tai lèmè sausosios biomasès derliaus padidèjimą $\left(0,10-0,13 \mathrm{~kg} \mathrm{~m}^{-2}\right)$. Tai patvirtino stipri šių rodikliu koreliacija: juostinio pasèlio koreliacijos koeficientas $(r)$ buvo 0,93 , mišraus $-r=0,92$, vienanario $-0,91(p<0,05)$.

Taigi, rykštines soras auginant siūlomais metodais, pagerès aplinkosauga ir bus gauta tvari biomasė biodegalams gaminti. Ilgalaikèje perspektyvoje tai gali sumažinti besivystančių šalių, taip pat ir Ukrainos, energetinę priklausomybę.

Reikšminiai žodžiai: biomasè, derlius, dirvožemio organinė medžiaga, dobilai, energiniai augalai, rykštinè sora. 